\title{
THE ANALYSIS OF SIGNIFICANCE DIFFERENCE IN WRITING ACHIEVEMENT AMONG THE STUDENTS WHO ARE INTROVERT, EXTROVERT, AND AMBIVERT
}

\author{
Yashori Revola \\ Alamsyah Harahap \\ Bambang Suwarno \\ University of Bengkulu \\ Email : revolory@yahoo.com
}

\begin{abstract}
The objective of this research was to investigate significant difference among personality types in students' writing achievement. The samples of the research comprised the third semester students of English Department of IAIN Bengkulu, academic year 2015/2016. The research design was ex - post facto. The result showed that the comparison result of writing achievement between introvert and extrovert types showed that Sig $<\alpha$, thus the alternative hypothesis was accepted. Comparison between introvert and ambivert types showed that Sig $<\alpha$, thus the alternative hypothesis was accepted. Then, comparison between extrovert and ambivert types showed Sig $>\alpha$, thus the alternative hypothesis was rejected. In conclusion, there was significance difference in writing achievement between introvert and both of extrovert and ambivert types. Meanwhile there was no significant difference in writing achievement between extrovert and ambivert types. This means that introvert students were stronger than extrovert and ambivert students in writing achievement of narrative text.
\end{abstract}

\section{Keywords: Introvert, Extrovert, Ambivert, Writing Achievement.}

Abstrak: Tujuan dari penelitian ini adalah untuk menyelidiki perbedaan yang signifikan antara tipe kepribadian dalam prestasi menulis siswa. Sampel dalam penelitian ini adalah mahasiswa semester III Jurusan Bahasa Inggris IAIN Bengkulu, tahun akademik 2015/2016. Desain penelitian ini adalah ex - post facto. Hasil penelitian menunjukkan bahwa hasil perbandingan prestasi menulis antara introvert dan ekstrovert menunjukkan bahwa Sig $<\alpha$, sehingga hipotesis alternatif diterima. Perbandingan antara introvert dan ambivert menunjukkan bahwa Sig $<\alpha$, sehingga hipotesis alternatif diterima. Kemudian, perbandingan antara ekstrovert dan ambivert menunjukkan Sig $>\alpha$, sehingga hipotesis alternatif ditolak. Kesimpulannya, ada perbedaan yang signifikan dalam prestasi menulis antara introvert dengan ekstrovert dan ambivertt. Sementara itu tidak ada perbedaan yang signifikan dalam prestasi menulis antara ekstrovert dan ambivert. Ini berarti bahwa siswa yang berkepribadian introvert lebih kuat dari ekstrovert dan ambivert dalam prestasi menulis teks naratif.

Kata Kunci: Introvert, Ekstrovert, Ambivert, Prestasi Menulis. 


\section{INTRODUCTION}

Writing is a subject in English language teaching curricula of State Islamic Institute of Bengkulu. The students get the subject when they are at second semester. Through writing activity, the students are expected to be able to express meaningful ideas in term of functional text and simple short essay. However, to write any kinds of paragraph is not easy because it needs more knowledge in writing a good passage. In writing a passage, students should pay attention and consider the characteristics of a good passage namely unity, coherence, and completeness. There are some problems that seem related to personality in writing skill such as difficulties in finding ideas, lack of grammar, lack of vocabulary, lack of exercise and lack of technical writing (Djuhari as cited in Nadrah $(3,2012)$ ).

Based on the the data of observation in learning process of writing class, the researcher found that each student had different achievement in all four English skills. Some students performed better in only a certain skill, not better for other skills. It could happens because there are many factors that influence the result of a study beside the treatment given by the lecturer or the quality of lecturer. Relating to the information, the researcher interviewed the writing lecturer in English Department of State Islamic Institut of Bengkulu on 25 October 2015. Based on the interview, there were students who got really high score while the others got really low score even though the students were taught with the same treatments.
Furthermore, the lecturer said that the students who tended to be physically less active and tend calm sometimes they tended to get high score, they also indicated by other factors that may influence the students' writing. The students writing capability is possibly influence by students personality. This is practically caused by active and passive personality that could influence the achievement of the students in writing.

There are two types of personality. They are extroversion and introversion. Extraversion is one of the variables in classifying type of personality. It refers to the relationship of extrovert-introvert personality. In this category, personality can be arranged into two types, they are extroversion and introversion. Then, extraversion is the act, state, or habit of being predominantly concerned with and obtaining gratification from what is outside the self while Introversionis "the state of tendency toward being wholly or predominantly concerned with and interested in one's own mental life"extraversion and introversion are part of a single continuum. Thus, a person who is high on extraversion is low on Introversion and vice versa (Shina and Fatima, 2013: 1). Besides, personality has been proven as one of element influencing performance in EFL. Both introvert and extrovert personality show difference achievement in speaking and writing of EFL. The students with extrovert personality seem better than those with introvert personality in speaking 
performance. However, in writing performance students with inrovert personality are more capable to deal with linguistic form and grammar ( Qomarudin cited in Hendarwan, 2012).

In accordance with previous discussion and theoretical empirical findings, researcher wants to investigate whether the personality is a factor that influences students' writing. That is why researcher is desire to investigate whether introvert students are different from extrovert and ambivert students or not in their writing achievement, or introvert students are even better in their writing especially in writing narrative text at the third semester students of English language teaching program.

According to Hougue (1997:02) Writing is a progressive activity. This means that when someone first writes something down, she has already been thinking about what he is going to say and how is going to say it. Then after he has finished writing, he reads over what he has written and makes changes and corrections. Based on Frendo (2005:81) stated that writing is a key part of the day-to-day activities that used in a vast range of different situations. It allows communication across time and space, and provides an invaluable medium for storing records and others information. Written communication offers different challenges from spoken interaction. In one way, writing is easier than speaking, in that it is not usually spontaneous and near instantaneous. Writing requires planing and organizational skills, as well as skill in linking paragraphs and sentences together, skill in spelling, punctuation, word order, word choice, and so on. According to Jhonson (2008:19), a process approach to writing instruction involves five stages such as prewriting, drafting, revising and editing, proof reading, and publishing.

Personality is one of the main topics in psychology. There have been many scientists who tried to make discussion about the meaning of personality. Until recently, there is no definition which is agreed by all scientists as the standard definition to explain the meaning of personality according to their point of views.

Extroverts are more energised when they have others around them. A cosy night in for them would probably involve about half a dozen friends or family as well as yourself and they love other people. Some other will love them with compassion and a genuine interest, others because they offer the opportunity to have an audience (Anthony, 2015: 01). They can also be very demanding, liking centre stage, and prepared to do almost anything to keep the spotlight on them. Extroverts need stimulation or they become bored quite quickly. Repetitive tasks will be a turn off unless they are fun or have some kind of payoff - like attention. Their concentration is span, particularly in solitary pursuits, tends to be shorter than introverts. They are happy to share their thoughts even if they have not been thought through fully. In addition the extroverts often are easier to 
change their minds than an introvert and they tend to have a wide circle of friends.

So far, we only know two types of personality: extrovert and introvert. However, there is one type of personality that go unnoticed: ambivert. In a study led by Dr. Grant, a psychologist at the University of Pennsylvania, explained that half of the total world population has a personality ambivert. Quoted from the Wall Street Journal, Dr. Grant explained that only a third of the world's population who have extrovert and introvert dominant.

Ambivert someone who has characteristics that exist in both classes. However, there is no dominant trait possessed by a ambivert. In studies on ambivert published in the journal Psychological Science in 2013, explained that the ambivert very easy to adapt to environmental conditions that can make an extrovert, or the introvert. From the study also made clear that an ambivert at a time will be very happy sociable, while at other times, too comfortable living alone. In fact, the study of ambivert already been done in 1920 by a researcher named Carl Jung. However, the concept of personality it just becomes a theory that he could not give a name. New in 1940, the type of personality ambivert could eventually be explained in detail.

\section{METHODS}

In this research, the researcher used a quantitative approach, an expost facto or causal comparative design, which contrasting the introvert, extrovert, and ambivert students' in writing achievement.
A quantitative approach intended to describe current condition, investigate relationships, and study cause-effect phenomena (Gay, 2000). Furthermore, in quantitative method the data is in numerical form and the analysis uses statistic (Sugiono, 2013). In this case, the researcher used this method to investigate the significance different in achievement among introverts, extroverts, and ambiverts in writing narrative text.

The population of this research was students in the third semester of English Department of IAIN Bengkulu academic year 2015-2016. There are four classes of the semester which are divided into A, B, C and, D. Each of the class consists of 30 students. The total of the sample that will be taken by the researcher is $50 \% \times 116=58$. In addition, taking the number of samples by following the sampling technique. Technique sampling is a technique to taking sampling (Sugiyono, 2010:56). The sampling technique using proportionate stratified random sampling technique. The reason using this technique because the population in this study is only the third semester students of English Department of IAIN Bengkulu that divided into four classes. So that all classes can be represented, then samples were taken from each class in the same proportion. The sampling procedure is by lottery. The reason using lottery is fairly simple for researchers and allowing injustice can be avoided.

Moreover, the research design was ex post facto and the procedure of this research 
were included determining the population and selecting the samples, distributing questionnaire, selecting writing test, conducting writing test, analyzing,

\section{Questionaire}

Firstly, the researcher gave the students questionaire in order to know their personality types. The Questionnaire consisted of 32 items. They also have to answer the following question $\mathrm{T}$ (True) or $\mathrm{F}$ (False). After the students answered the question, they add up the true answer and check the scoring at the end of the list to see if they are an introvert, an extrovert, or an ambivert.

\section{Writing test}

In this study, writing test as the instrument of the study. The researcher asked the students to choose which topic they like and write it in narrative text. Then, the researcher checking out the the

\begin{tabular}{|c|c|l|}
\hline No & Interval & Category \\
\hline 1 & $\mathbf{8 6 , 9}-100$ & Very Good \\
\hline 2 & $\mathbf{7 3 , 7 - 8 6 , 8}$ & Good \\
\hline 3 & $\mathbf{6 0 , 5}-\mathbf{7 3 , 6}$ & Fair \\
\hline 4 & $\mathbf{4 7 , 3 - 6 0 , 4}$ & Poor \\
\hline $\mathbf{5}$ & $\mathbf{3 4 , 1 - 4 7 , 2}$ & Very Poor \\
\hline
\end{tabular}

(Weigle Sara Cushing. 2002)

In this research, the researcher used questionnaire as the tool to know the students' personality wheter extrovert, middle of continuum or introvert. The questionnaire was taken, and translated into Bahasa Indonesia in order to minimize the misinterpretation by the students. The Questionnaire consisted of 32 items. They interpreting and concluding the data. In collecting the data, the researcher used two stages as follow;

result of the test. After that, the result would be classified based on their group of personality to find out whether introvert students are different from extrovert students or not in their writing achievement, or introvert students are even better in their writing achievement especially in writing narrative text by analyzing students writing ability.

On the other hand, the scoring analysis on writing skill of the students that used by the researcher was as follow:

$$
\begin{aligned}
& \text { MAXn }- \text { MINn } \\
& \mathrm{R}=100-34=66 \\
& \text { Interval }=\frac{R}{n_{c}}=\frac{66}{5}=13,2
\end{aligned}
$$


middle of the continuum 10-19, and extrovert is 1-9. Then, after known the personality of the students, the researcher devided the scores of writing based on their personality.In analyzing the data, the researcher used t-test to determine whether there are differences in outcomes between the groups writing introvert, extrovert, and ambivert into write a simple paragraph in the form of narrative text on the third semester of English Department IAIN Bengkulu academic year 2014 - 2015. The tests of difference employ the SPSS 20. The value of this research is a test of the three groups, then significance testing using ttest.

If $F$ count $\leq F$ table, the $A$ formula is used

It means that the both samples have equal variance. Thus, we used the t-test for independent score were equal variants (formula A). The formula as follow:

$t_{\text {count }}=\frac{X_{1}-X_{2}}{S_{\text {diff }}}$

$X_{1}=\frac{\sum X_{1}}{N_{1}} ; X_{2}=\frac{\sum X_{2}}{N_{2}}$

$S_{\text {diff }}=\sqrt{\frac{\sum x_{i}{ }^{2}-\frac{\left(\sum x_{1}\right)}{N_{1}}+\sum x_{2}{ }^{2}-\frac{\left(\sum X_{2}\right)}{N_{2}}}{N_{1}+N_{2}-2}} \llbracket \frac{1}{N_{1}}+\frac{1}{N_{2}} \rrbracket$

\section{If $F$ count $\geq F$ tables, the $B$ formula is} used

$t_{\text {count }}=\frac{X_{1}-X_{2}}{\sqrt{\frac{s_{1}^{2}}{N_{1}-1}}+\frac{S_{1}^{2}}{N_{1}-1}}$

The $\mathrm{t}$ form of the formula will be called $\mathrm{t}$ count. $\mathrm{T}$ count will be compared to t-table at $\alpha=0.05$ and corresponding $d f$ two result may occur:
If $t_{\text {count }}>t_{\text {table }} ; H_{1}$ will be accepted and $H_{0}$ will rejected.

If $t_{\text {count }}<t_{\text {table }} ; H_{0}$ will be accepted and $H_{1}$ will rejected.

The calculation of t-test for writing test in this research was compared to watch out the writing achievement between introverts and extroverts, introverts and ambiverts, and extroverts and ambiverts.

\section{RESULT AND DISCUSSION \\ Result Validity and Reliability of the Questionaire}

To know the validity and reliability, the questionnaire was given to the fifth semesters students of English department of IAIN Bengkulu academic year 2014/2015 as the try out. The draft consisted of 80 items of questionnaires. Only 32 items of the questionnaire were focused to be valid and the reliable was used Cronbach alpha coefficient between 0 and 1 . The result showed that the alpha was $0.890(\alpha>0.5)$.

\section{Personality Types of the Students}

The questionnaire test was done to classify the sample into groups based one their type of personality. The test was distributed in the first meeting in each sample class. It consisted of 32 item, and it was administered in 10 minutes. Based on the result of the test, the researcher analyzed the score then grouped the sample. Out of 58 students who followed the test, 23 students or $39.7 \%$ are classified into introvert, 27 students or $46.5 \%$ are classified into extrovert. And the other 8 students or 13.8 $\%$ are put into middle of the continuum or ambiverts group. 


\section{Writing Achievement}

After doing the analysis, the result are performed in the table bellow:

Table 1: The Distribution of Frequences of Writing Test Category

\begin{tabular}{|c|c|c|c|}
\hline No & Interval & Frequency & Percentage (\%) \\
\hline $\mathbf{1}$ & $\mathbf{8 6 , 9 - 1 0 0}$ & 4 & 6,9 \\
\hline $\mathbf{2}$ & $\mathbf{7 3 , 7}-\mathbf{8 6 , 8}$ & 43 & 74,14 \\
\hline $\mathbf{3}$ & $\mathbf{6 0 , 5}-\mathbf{7 3 , 6}$ & 11 & 18,96 \\
\hline $\mathbf{4}$ & $\mathbf{4 7 , 3}-\mathbf{6 0 , 4}$ & 0 & 0 \\
\hline $\mathbf{5}$ & $\mathbf{3 4 , 1}-\mathbf{4 7 , 2}$ & 0 & 0 \\
\hline & Total & $\mathbf{5 8}$ & $\mathbf{1 0 0} \%$ \\
\hline
\end{tabular}

The table above showed the distribution of frequences of writing test category. The table described that the students who got very good was $6,9 \%$. Then, there were 43 students got good score with percentage $74,14 \%$. Meanwhile, there were also 11 students got fair score with percentage $18,96 \%$ and there were not students who got poor and very poor score in this composite score of writing test.

Table 2: Writing Achievement of the Student Based on Personality Type

\begin{tabular}{|c|c|c|c|c|c|c|}
\hline \multirow{2}{*}{ Personality Type } & \multicolumn{5}{|c|}{ Writing Achievement Category } & \multirow{2}{*}{} \\
\cline { 2 - 6 } & $\begin{array}{c}\text { Very } \\
\text { Good } \\
(\%)\end{array}$ & $\begin{array}{c}\text { Good } \\
(\%)\end{array}$ & $\begin{array}{c}\text { Fair } \\
(\%)\end{array}$ & $\begin{array}{c}\text { Poor } \\
(\%)\end{array}$ & $\begin{array}{c}\text { Very } \\
\text { Poor } \\
(\%)\end{array}$ & $\begin{array}{c}\text { Percentage } \\
(\%)\end{array}$ \\
\hline Introvert & 6,90 & 32,76 & 0 & 0 & 0 & $\mathbf{3 9 , 6 6}$ \\
\hline Extrovert & 0 & 27,59 & 10,34 & 0 & 0 & $\mathbf{4 6 , 5 5}$ \\
\hline Ambivert & 0 & 18,96 & 3,45 & 0 & 0 & $\mathbf{1 3 , 7 9}$ \\
\hline Total & $\mathbf{6 , 9 0}$ & $\mathbf{7 9 , 3 1}$ & $\mathbf{1 3 , 7 9}$ & $\mathbf{0}$ & $\mathbf{0}$ & $\mathbf{1 0 0 \%}$ \\
\hline
\end{tabular}

The table above showed the total of the student based on their personality type in writing achievement categories. It showed that the student who got very good were $6,90 \%$ students that consist of 1 introvert. Then, 79,31\% students got good score that 
consist of $32,76 \%$ introvert, $27,59 \%$ extrovert, and $18,96 \%$ ambivert. After that, there were $13,79 \%$ students got fair score that consist of $10,34 \%$ extrovert and $3,45 \%$ Hyphotesis Testing ambivert. Meanwhile, there were not students who got poor and very poor score in this composite score of writing test.

Table 3: Group Statistic Between Introvert and Extrovert

\begin{tabular}{|c|c|c|c|c|}
\hline Personality Type & Mean Score & t-count & Sig & Remark \\
\hline Introvert & 82,32 & 5,806 & $(0.000<0,05)$ & $\mathrm{S}$ \\
\hline Extrovert & 74,14 & & & \\
\hline
\end{tabular}

Note: $\mathrm{S}=$ Significance

The table above showed that sig $=0,00, \quad<\alpha$, (2-tailed test, $\alpha=5 \%$ ). Thus, the $\alpha=0,05$. It was found that the value of Sig difference in means is significant.

Table 4: Group Statistic Between Introvert and Ambivert

\begin{tabular}{|c|c|c|c|c|}
\hline Personality Type & Mean Score & t-count & Sig & Remark \\
\hline Introvert & 82,32 & 3,95 & $(0,02<0,05)$ & $\mathrm{S}$ \\
\hline Ambivert & 74,59 & & & \\
\hline
\end{tabular}

Note: $\mathrm{S}=$ Significance

The table above showed that $\operatorname{sig}=0,02, \quad<\alpha$, (2-tailed test, $\alpha=5 \%$ ). Accordingly, $\alpha=0,05$. It was found that the value of Sig the difference in means is significant.

Table 5: Group Statistic Between Extrovert and Ambivert

\begin{tabular}{|c|c|c|c|c|}
\hline Personality Type & $\begin{array}{c}\text { Mean } \\
\text { Score }\end{array}$ & t-count & Sig & Remark \\
\hline Extrovert & 74,14 & \multirow{2}{*}{0,21} & $(0,83>0,05)$ & NS \\
\hline Ambivert & 74,59 & & & \\
\hline
\end{tabular}

Note: NS = Not Signigficance 
The table above showed that Sig = $0,83, \alpha=0,05$. It was found that the value of Sig $>0,05$, (2-tailed test, $\alpha=5 \%$ ). Furthermore, the difference in means is not significant. Based on the result of the statistic analysis above, the researcher can summarize the t-test result as the table bellow:

Table 6: Summary of The Significance Difference In Writing Achievement Among The Students Personality Types

\begin{tabular}{|c|c|c|c|}
\hline Personality Type & Introvert & Extrovert & Ambivert \\
\hline Introvert & - & Sig & Not Sig \\
\hline Extrovert & Sig & - & - \\
\hline Ambivert & Sig & Not Sig & \\
\hline
\end{tabular}

The table above showed that there was significance different of writing achievement between introvert students with both of extrovert and ambivert students. Meanwhile, there was no significance difference of writing achievement between extroverts and ambivert students.

\section{DISCUSSION}

In this research, the researcher carry out 3 times test between introvert and extrovert student, introvert and ambivert student, and extrovert with ambivert student. First, the $\mathrm{t}$ test result between introvert and extrovert was that $\mathrm{Ha}$ is accepted. Second, the $\mathrm{t}$ test result between introvert and ambivert was that $\mathrm{Ha}$ is accepted too. Finally the third, the $t$ test result between extrovert and ambivert was that Ha is rejected.

Based on the result above, the researcher found that the introvert students has better achievement in writing than the extrovert and ambivert student; especially the student at the third semester of English department of IAIN Bengkulu. It is probably more related to their characteristics as an introvert. Since the introvert characteristics which are thoughtful, careful, and passive support them to have better performance in writing. Meanwhile the extrovert characteristics that are talkactive, sociable, and active even; the ambivert students who always changeble that could not be predicted what is their personality exactly that support them to have better performance in the other skill, i.e., speaking.

The characters of someone who is introvert are like to stay alone, not really friendly but to close friends, does not like interaction with other people, passive, pessimistic, not aggressive, like reading than chatting, shy typed, considerate, does not like crowd, calm, stable, love monotonous work. Furthermore, Young as cited in Soufi (2012:613) explain some more details of the characteristics of extroversion and introversion. He state that 
Extroverted person directs vital energy (libido) to outside the self and focus on external events, people and situations that is highly under the influence of environmental forces, friendly and confident. Whereas, introverted person directs libido flows to inside the self. Introverted person are more perspective andresistant against external influences. They are less confident and less friendly in relation to others and outside the world compared to extroverted person extrovert people are usually fluent in speaking, free of feeling worry and not easily get ashamed and awkward, love to work with others, and good at adapting with their surroundings. They also put interest in athletic. In the other hand, introvert people are more fluent in writing than speaking, tend to be serious and anxious, like working alone, often find difficulty in behaving, and love to read. Whereas, an ambivert people is those who has characteristics that exist in both classes.

However, there is no dominant trait possessed by a ambivert. In a study of ambivert report published in the journal Psychological Science in 2013, explained that the ambivert very easy to adapt to environmental conditions that can make an extrovert, or the introvert.

In classroom particularly, one needs to be able to master exercise, drills, and other analytical oral and written activities. Considering the characteristics of introvert students which is thoughtful and tend to be analytical, it is speculated that introvert student will perform better in writing rather than extrovert student does. Above statement is supported by the result of a research done by Shahila (2012:33). Her study done to Extroversion-introversion and risk-taking in the context of second language acquisition. The result show that introvert personality be better suited to classroom learning, especially reading and writing skills. Similar result can also be found in Mukundan (2011:161). His study indicate that personality type had no significant effect on learners progress in writing. Nevertheless, self-correction method showed to be significanly effective at 0.5 .

In addition, The statement above was supported by opinion of Muslim (2014:105) that to master writing, one should read a lot because better writer tends to be better reader. Academic writing assigment require students to master the knowledge of good writing. Evaluation judgments of the different fields of learning are mainly based upon writing. Student who are skilled in writing can get better grades than those who are unskilled. Thus, the basic of good writing should be taught and practiced from the early year of learning. On the basis of the previous paragraphs, the researcher assumed that introvert students would perform better in writing. It is due to the fact that introvert students pose those characteristics which are in line with writing process. In order to produce a good writing, one needs to consider many principles in order for the writing to be understandable by the readers. In short, it is a complicated process that requires time and 
a lot of thought, something that extrovert people do not really like.

Furthermore, students who are ambivert actually have some qualities of the introvert and some of the extrovert. It means that if there is a factor which influence them, the personality types might be changed. In other words, the personality types of the middle of the continuum or ambivert students are changeable. When they answered the questionnaire, it could not predict what is their personality exactly. Eventhough they could us predicted what is their personality exactly, but the researcher keep decided them to be calculate. The result of the calculation as explained before.

In this study, the extrovert people can build better communication with other people since they are sociable and openminded whereas the introvert people who are passive and just liking solitary activity made them to be used to listen other people speaks. This statement is supported by Muharrami (2013:08) that extrovert people are usually fluent in speaking, free of feeling worry and not easily get ashamed and awkward, love to work with others, and good at adapting with their surroundings. However, there is no dominant trait possessed by a ambivert. In a study of ambivert report published in the journal Psychological Science in 2013, explained that the ambivert very easy to adapt to environmental conditions that can make an extrovert, or the introvert.

Furthermore, students who are ambivert actually have some qualities of the introvert and some of the extrovert. It means that if there is a factor which influence them, the personality types might be changed. In other words, the personality types of the middle of the continuum or ambivert students are changeable. When they answered the questionnaire, it could not predict what is their personality exactly. Eventhough they could us predicted what is their personality exactly, but the researcher keep decided them to be calculate. The result of the calculation as explained before.

Having known the result of this study as stated previously and as related to the some theories and previous study, this research, this research presented the positive side and negative side or the weaknesses and the strengths of this study. Specifically this study is the further study of some debatable or arguable about the differences achievement between the introvert and the extrovert in the context of foreign language acquisition through learning activity in particular setting of school institution. Therefore, theoretically this study supported and strengthened related theory that considers that the introvert got better writing achievement than those extrovert. The other strength of this study was different from other studies that only focused on the introvert and the extrovert meanwhile this study not only on those variables but also the hidden which was not covered in previous study where this study also investigated the achievement of ambivert in writing.

From this study, it indicated that the students with the ambivert got better achievement that closely similar with the 
extrovert achievement. In addition, the weaknesses of this study was that this study used limited samples and also need more related theories particularly that can support the finding of this study related to the ambivert achievement in writing because there was no any researches or theories found by researcher related to the ambivert as implied in this study. Therefore, it is important to find out information and to do further study related to the ambivert characteristics.

Relating to the research discussion, this research contributes theoretical and empirical finding, as consideration to the teaching English as foreign language in education particularly for EFL teachers to give attention on the variety of characters of their students in their classroom because the characteristics can be the gap among the students in the term of achievement in writing as implied on previous discussion. Thus, in the teaching of writing for EFL, it is important for the teachers to give extra attention to the extroverts and ambivert students in writing class because their writing is significantly lower than the introvert students.

\section{Conclusion And Suggestion}

In this study, the researcher found that 23 students or $39.7 \%$ are classified into introvert, 27 students or $46.5 \%$ are classified into extrovert. And the other 8 students or $13.8 \%$ are classified into ambiverts group. Moreover, there was significant different achievement in writing ability among personality types. The students of introvert type have better result than extrovert type in writing skill test as well as the students of introvert type have better result than ambivert type in writing skill test. Meanwhile, the students of extrovert type have almost the same result as ambivert type in writing skill test.

Since personality influenced students' achievement in writing, EFL teachers are suggested to pay more attention to their students personality types at their classroom. It is necessary for the teachers to know all students' personality and they have to attempt to make balances among introvert students and extrovert students . That is why through this study it is recomended for the EFL writing teachers to give more attention to the students who are extroverts and ambivert because the students with the characteristics tended to get less success result than the introverts.

Furthermore, Since the study provided the information related to the personality contribution on students writing achievement, the researcher recommended for other researchers to find out further scientific investigation to strengthen the finding of this study in order to answer the natural phenomenon factor found in this study comprehensibly which is related to the personality effects in writing English as foreign language.

\section{REFERENCE}

Anthony. (2015). Extrovert and Introvert. Retrieved December 10, 2015, from http://www.hillinghypnotherapy.co.uk/personalit y-test-online/personality-testing-explained/ extrovert-and-introvert-what-is-the-difference/ 
Fatima, S and Sinha, A. (2013). Impact of extrovertintrovert personality on individually's level of creativity: an emperical study. Indian journal applied research, Vol. 3. Issue: 12. Dec 2013: ISSN-2249-555x: National Institute of Technology, India.

Frendo, E. (2005). How to teach business english. Pearson Education Limited: Longman Gay, L.R and Airasian, P. (2000). Educational research: competences for analysis and application. USA: Prentice Hall.

Herdawan, D. 2012. A comparative study of students, writing achievement between extrovert and introvert students' personality at the second year of SMAN 7 Bandar Lampung. Lampung: University of Lampung.

Hogue, Alice Oshima Ann. (1997). Writing academic english, New York: Addison Wesley Longman.

Jhonson, Andrew P. (2008). Teaching reading and writing. United Kingdom.

Muslim, I.M. (2014). Helping EFL students improve their writing. International Journal of Humanities and Social Science, Vol. 4 No. 2 (special issueJanuary 2014): Baghdad University.

Mukundan, J. (2011). Impact of self-comection on extrovert and introvert students in EFL writing progress. English languange Teaching. Journal of
Canadian Center of Science and Education, Vol. 4, No. 2; June 2011: Universiti Putra Malaysia.

Muharrami, L.(2013). A comparative study between introvert and extrovert students personality in listening achievement. http://jumal.fkip.unila.ac. id/ index.php/123/article/view/1538, Vol2, No 8 (2013).

Nadrah. (2012). Assesment in improving students' writing ability. Jurnal Bahasa Al-Lughah, Vol. 1 No.2 Desember 2012, ISSN: 2302-9986: IAIN Bengkulu/ (2), 1-12.

Soufi, M. (2012). The studying of the relationship between personality type (Extrovert or Introvert) and personals organizational citizen behaviour. Interdisciplinary Journal of Contemporary Research in Business, Vol. 4 No. 8: Islamic Azad University.

Sugiyono. 2013. Metode penelitian kuantitatif, kualitatif. Bandung: Alfabeta.

Shahila, Z (2012). A study on the relationship between extroversion-introversion and risk-taking in the context of second language acquisition. International Journal of Research Studies in Language Learning, Volume 1 Number 1, 3340.

Weigle, Sara Cushing. 2002. Assessing writing, Cambridge: Cambridge University Press. 